\title{
The Impact of Farming on Children's Critical Thinking Ability in Indonesia
}

\author{
Tesya Cahyani Kusuma ${ }^{1, *}$ Yessi Rifmasari ${ }^{1}$
}

\author{
${ }^{1}$ STKIP ADZKIA, Padang, Indonesia \\ *Corresponding author. Email: t.c.kusuma@stkipadzkia.ac.id
}

\begin{abstract}
The phenomenon showed that the level of critical thinking ability of children aged 5-6 years was low. This paper used quasi experimental nonequivalent group pretest - postest designed which applied purposive sampling techniques. The results showed that there was an impact of farming to children's critical thinking ability of kindergarten's students in Indonesia (t-count $>t$-table; $1.205>0.05)$. Additionally, it revealed that $76.47 \%$ of children were able to solve simple problems while $88.23 \%$ of children were able to complete their own tasks. It can be concluded that the ability of children to solve their own problems and to complete tasks when facing difficulties were low. In line with cognitive development, critical thinking can be developed in early childhood by using materials and methods that actively involved children to assist them to construct their own knowledge such as farming. Through that activity, children stimulated to do observing, identifying and analyzing.
\end{abstract}

Keywords: Critical thinking, learning methods, farming

\section{INTRODUCTION}

Cognitive is an ability related to perceptions, thoughts, memories, and information processing that enables a person to gain knowledge, solve problems and plan for the future or all psychological processes related to how individuals learn, pay attention, assess, and think about their environment (Desmita, 2010, p. 153). According to Susanto (2012, p. 47), Cognitive is a process of thinking, namely the ability of individuals to connect, assess, and consider an event. One ability of cognitive development is critical thinking. As the specific purpose of Early Childhood Education (ECE) is that all children are able to think critically, give reasons, solve problems and find causal relationships (Rahman, 2005, p. 7). Critical thinking is the ability to make rational decisions about what to do or what to believe (Slavin, 2011, p. 37). Learning methods that actively involve children are the most appropriate methods for building their own knowledge, such as in experimental activities, children do by themselves and conclude the results of their experiments, one of which can be done through farming activities, so that the ability to think critically children can be developed. According to Yasbiati, Giyartini, \& Lutfiana (2017, p. 203), planting is an activity planned and carried out by children and teachers, this activity aims to foster children's interests of plants and the environment. In addition, farming activities can also develop children's critical thinking skills. According to Piaget (1972, p. 49-91) starting from a general description of cognitive development phase mentioned above, it can be seen that the cognitive development of early childhood is in a pre-operational phase which includes three aspects, namely symbolic thinking, egocentric thinking, and intuitive thinking. Nugraha $(2008$, p. 39) mentioned that critical thinking skills can be developed in early childhood by using materials and methods that are appropriate to the stages of children's thinking abilities which are still concrete. Natalina (2015, p. 3) cited in Ennis (1996) claims six basic aspects of critical thinking known as FRISCO; Focus, Reasons, Inference, Situations, Clarity, and Overview. Furthermore, agriculture is a human effort in farming where the object is an empty land. Rahima (2018, p. 72) declared that growing vegetables in polybags or pots is the simplest method of planting. It can even use unused containers such as buckets, paint cans, or drums. Types of plants are usually cultivated that can be used for family needs, such as spinach. According to Ratnasari, Sujana, \& Pudyaningtyas, (2016, p. 2) farming activities provide opportunities for children to explore and observe the surrounding environment and gave the freedom to develop imagination and embodied the meaning of learning while playing.

\section{METHOD}

The research used quantitative approach with the experimental method in the form of quasi-experimental. Sugiyono (2011, p. 72) states that the experimental method is a research method used to look for the impactimpact of certain treatments on others, under controlled conditions. The Experimental Research Design is as follows:

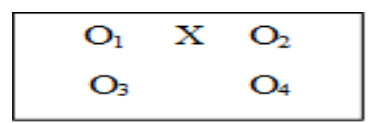

Figure 1 Experimental research design 
The form of design used was sampling purpose which aimed to determine the impact of independent variables on the dependent variable carried out through farming activities. As stated by Sugiyono (2011, p. 116) that: this quasi experimental design was used because in reality it was difficult to get a control group used for research where there were two groups that were not randomly selected and then given a pre-test to find out the initial conditions. There weredifferences between the experimental group and control group. The population in this study were all kindergartens in Indonesia, totaling 47 children consisting of 25 girls and 22 boys. The sampling technique used in this study was purposive sampling technique to describe a certain consideration. Additionally, the experimental group BI consisted of 8 boys and 9 girls whereas the control group consisted of 8 boys and 9 girls.

To get clear information related to the study, structured interviews also used to teacher of experimental group Table 1 Grids of farming activity instrumen
(Sugiyono, 2017, p.138). Moreover, the researcher analyzed the lesson plans (RPPH), observation sheets, photos, and videos in order to give a real data of the learning activities through farming activities.

The procedures of this research conducted in three stages: 1) Preparation stage consists of Establishing themes and sub-themes, Designing and preparing RPPH, Making the research instrument grids, establishing the experimental and control classes; 2) Implementation phase consists of providing lesson plan (RPPH) which in the B1 group experimental class, learning was carried out with farming activities whereas in the control group B2, learning is carried out using conventional media with pictures as media; 3) Completion stage includes assessing pretest posttest, analyzing test results, conducting normality test and homogeneity test, doing t-test, and drawing conclusion. The development of farming activities instruments was carried out by making the following grids:

\begin{tabular}{|c|c|c|c|c|c|}
\hline No & Indicator & Sub Indicator & Aspects observed & $\begin{array}{l}\text { Technical } \\
\text { collection }\end{array}$ & Source \\
\hline 1 & $\begin{array}{c}\text { Knowing how it relates to } \\
\text { nature }\end{array}$ & $\begin{array}{l}\text { Trying to } \\
\text { directly plant } \\
\text { spinach } \\
\end{array}$ & $\begin{array}{c}\text { Children are able to do } \\
\text { spinach farming } \\
\text { activities }\end{array}$ & $\begin{array}{c}\text { Obser-vation } \\
\text { Documentation }\end{array}$ & $\begin{array}{l}\text { Children's } \\
\text { Activity }\end{array}$ \\
\hline 2 & $\begin{array}{l}\text { Knowing the relationship } \\
\text { with nature }\end{array}$ & $\begin{array}{l}\text { Questions \& } \\
\text { answers about } \\
\text { the process of } \\
\text { growing } \\
\text { spinach }\end{array}$ & $\begin{array}{c}\text { Children are able to } \\
\text { observe/ observe spinach } \\
\text { vegetables critically or } \\
\text { deeply }\end{array}$ & $\begin{array}{c}\text { Obser-vation } \\
\text { Documenta-tion }\end{array}$ & $\begin{array}{l}\text { Children's } \\
\text { Activity }\end{array}$ \\
\hline 3 & $\begin{array}{l}\text { Knowing the cause and } \\
\text { impact about the } \\
\text { environment }\end{array}$ & $\begin{array}{l}\text { Trying to tell } \\
\text { what happens } \\
\text { if vegetables } \\
\text { (plants) are } \\
\text { not watered } \\
\text { and fertilized }\end{array}$ & $\begin{array}{l}\text { The child is able to } \\
\text { analyze the differences in } \\
\text { plants (which are } \\
\text { fertilized and watered } \\
\text { with those that are not } \\
\text { and the growth of } \\
\text { spinach vegetable } \\
\text { planting from day to day }\end{array}$ & $\begin{array}{c}\text { Obser-vation } \\
\text { Documenta-tion }\end{array}$ & $\begin{array}{l}\text { Children's } \\
\text { Activity }\end{array}$ \\
\hline
\end{tabular}

Rubric of critical thinking ability assessment as follows: The instrument for evaluating children's learning used a checklist format. Checklist format, containing progress indicators to measure the success of objectives and basic competencies set in the weekly lesson plan (RPPM).
Referring to the 2013 Curriculum the assessment sheet in this study used a checklist as follows: 
Table 2 Rubric assessment capability of critical thinking

\begin{tabular}{|c|c|c|c|c|c|}
\hline \multirow[t]{2}{*}{ No } & \multirow[t]{2}{*}{$\begin{array}{l}\text { Aspects } \\
\text { observed }\end{array}$} & $\begin{array}{l}\text { Were developed } \\
\text { very well } \\
\text { (BSB) }\end{array}$ & $\begin{array}{l}\text { Develops as } \\
\text { Expected } \\
\text { (BSH) }\end{array}$ & $\begin{array}{l}\text { Begins to } \\
\text { Develop } \\
\text { (MB) }\end{array}$ & $\begin{array}{l}\text { Not yet } \\
\text { Developed } \\
\text { (BB) }\end{array}$ \\
\hline & & (4) & (3) & (2) & (1) \\
\hline 1 & $\begin{array}{c}\text { Children are } \\
\text { able to observe/ } \\
\text { observe spinach } \\
\text { vegetables } \\
\text { critically or in } \\
\text { depth }\end{array}$ & $\begin{array}{l}\text { Children are able to } \\
\text { do spinach farming } \\
\text { activities without } \\
\text { assistance }\end{array}$ & $\begin{array}{l}\text { Children are able to } \\
\text { do spinach farming } \\
\text { activities but are still } \\
\text { assisted }\end{array}$ & $\begin{array}{l}\text { Children are able } \\
\text { to do spinach } \\
\text { farming activities } \\
\text { but are often } \\
\text { assisted }\end{array}$ & $\begin{array}{l}\text { Children are not } \\
\text { able to do spinach } \\
\text { vegetables at all }\end{array}$ \\
\hline 2 & $\begin{array}{c}\text { Children are } \\
\text { able to observe / } \\
\text { observe spinach } \\
\text { vegetables } \\
\text { critically or } \\
\text { deeply }\end{array}$ & $\begin{array}{l}\text { Children are able to } \\
\text { express questions } \\
\text { about spinach } \\
\text { vegetables critically } \\
\text { or deeply }\end{array}$ & $\begin{array}{l}\text { With-out being } \\
\text { helped, the child is } \\
\text { able to express } \\
\text { questions about } \\
\text { spinach vegetables } \\
\text { critically or deeply } \\
\text { but is still helped. }\end{array}$ & $\begin{array}{c}\text { Children are able } \\
\text { to express } \\
\text { questions about } \\
\text { spinach } \\
\text { vegetables } \\
\text { critically or } \\
\text { deeply but are } \\
\text { often helped. }\end{array}$ & $\begin{array}{l}\text { Children are not } \\
\text { able to } 1 \text { express } \\
\text { questions about } \\
\text { spinach } \\
\text { vegetables } \\
\text { critically deeply }\end{array}$ \\
\hline 3 & $\begin{array}{l}\text { Children are } \\
\text { able to analyze } \\
\text { the difference } \\
\text { between plants } \\
\text { (which are } \\
\text { fertilized and } \\
\text { watered with } \\
\text { those that are } \\
\text { not, and the } \\
\text { growth of } \\
\text { spinach from } \\
\text { day to day) }\end{array}$ & $\begin{array}{l}\text { Children are able to } \\
\text { analyze the } \\
\text { differences in plants } \\
\text { (which are fertilized } \\
\text { and watered with } \\
\text { those that are not and } \\
\text { the growth of spinach } \\
\text { from day to day) } \\
\text { critically without } \\
\text { assistance }\end{array}$ & $\begin{array}{l}\text { Children are able to } \\
\text { analyze differences in } \\
\text { plants (which are } \\
\text { fertilized and watered } \\
\text { with those that are } \\
\text { not and the growth of } \\
\text { spinach from day to } \\
\text { day) critically but } \\
\text { still assisted }\end{array}$ & $\begin{array}{c}\text { Children are able } \\
\text { to analyze } \\
\text { differences in } \\
\text { plants (which are } \\
\text { fertilized and } \\
\text { watered with } \\
\text { those that are not } \\
\text { and plant growth } \\
\text { spinach from day } \\
\text { to day critically } \\
\text { but often helped }\end{array}$ & $\begin{array}{l}\text { Children are not } \\
\text { able to llanalyze } \\
\text { differences } \\
\text { inplants (which } \\
\text { are fertilized and } \\
\text { watered with } \\
\text { those that are not } \\
\text { and the growth of } \\
\text { spinach from day } \\
\text { to day) critically }\end{array}$ \\
\hline
\end{tabular}

Data collection can be done in a variety of settings, various sources, and various ways (Sugiyono, 2017, p. 137).

So, the researcher decided to collect the data through interviews and observations. The observation sheet of child development assessment can be seen below.

\section{Table 3 Child development assessment sheet/ observation sheet}

\begin{tabular}{|c|c|c|c|c|c|c|c|c|c|c|c|c|c|}
\hline \multirow{3}{*}{ No } & \multirow{3}{*}{ Name } & \multicolumn{4}{|c|}{$\begin{array}{c}\text { Children are able to do spinach } \\
\text { activities }\end{array}$} & \multicolumn{4}{|c|}{$\begin{array}{l}\text { Children are able to observe } \\
\text { spinach critically or deeply }\end{array}$} & \multicolumn{4}{|c|}{$\begin{array}{l}\text { Children are able to analyze the } \\
\text { differences in plants (spinach) }\end{array}$} \\
\hline & & BSB & BSH & MB & BB & BSB & BSH & MB & BB & BSB & BSH & MB & BB \\
\hline & & 4 & 3 & 2 & 1 & 4 & 3 & 2 & 1 & 4 & 3 & 2 & 1 \\
\hline 1. & A & & & & & & & & & & & & \\
\hline 2. & A & & & & & & & & & & & & \\
\hline 3. & etc & & & & & & & & & & & & \\
\hline
\end{tabular}

The data were analyzed by t-test after passing the normality test and homogeneity test (Syafril, 2010, p.211). The structured observation used to get the result systematically
(Sugiyono, 2017, p. 146). Furthermore, the report of child development assessment can be seen below. 
Table 4 Child development assessment report/ observation sheet doing spinach vegetable activity

\begin{tabular}{|c|c|c|c|c|c|c|c|c|c|c|c|c|c|}
\hline \multirow{3}{*}{ No } & \multirow{3}{*}{ Name } & \multicolumn{4}{|c|}{$\begin{array}{c}\text { Children are able to plant } \\
\text { spinach }\end{array}$} & \multicolumn{4}{|c|}{$\begin{array}{l}\text { Children are able to obrserve } \\
\text { spinach critically or deeply }\end{array}$} & \multicolumn{4}{|c|}{$\begin{array}{l}\text { Children are able to analyze the } \\
\text { differences of plant (spinach) }\end{array}$} \\
\hline & & BSB & BSH & MB & BB & BSB & BSH & MB & BB & BSB & BSH & MB & BB \\
\hline & & 4 & 3 & 2 & 1 & 4 & 3 & 2 & 1 & 4 & 3 & 2 & 1 \\
\hline 1. & A & & & & & & & & & & & & \\
\hline 2. & A & & & & & & & & & & & & \\
\hline 3. & etc & & & & & & & & & & & & \\
\hline
\end{tabular}

\section{Result and Discussion}

Normality test was conducted to determine whether the data distributed normally or not (Syafril, 2010, p. 211). Kolmogorov-Smirnov normality test used in this study utilizing SPSS 18 version. The results showed the pre- test data obtained 0.772 and Sig. (p) 0.590 for experimental group while Kolmogorov-Smirnov value on the post-test data was, 1.205 and Sig. (p) 0.110. Meanwhile, the Kolmogorov-Smirnov value on the pre-test data obtained 1.083 and Sig (p) 0.191 while the Kolmogorov-Smirnov value in the post-test data 1.029 and Sig. (p) 0.240 for control group. Using a significance of 0.05 , the data both groups were distributed normally (the value of sig. $(p)>\alpha$ ). The calculation could be seen in table below.

Table 5 Calculation results for pre-test normality test, post-test experiment class and control class

\begin{tabular}{|c|c|c|c|c|c|c|}
\hline No & Class & N & A & K-S & Sig. $(\boldsymbol{p})$ & Information \\
\hline 1 & Pre-test Experiment & 17 & 0,05 & 0,772 & 0,590 & Normal \\
\hline 2 & Pre-test control & 17 & 0,05 & 1,083 & 0,191 & Normal \\
\hline 3 & Post-test experiment & 17 & 0,05 & 1,205 & 0,110 & Normal \\
\hline 4 & Post-test control & 17 & 0,05 & 1,029 & 0,240 & Normal \\
\hline
\end{tabular}

Afterwards, the homogeneity test conducted to find out that the sample class data homogenous or not (Syafril, 2010, p. 69). By looking at Levene statistics, the result showed that the pre-test data were homogenous (Sig. $(p): 0.117>0.05$ ) whereas the post-test data were homogenous as well (Sig. $(p): 0.826>0.05)$. The homogeneity test can be seen in the table below.

\section{Table 6 Homogeneity test results of experiment class and control class}

\begin{tabular}{|c|c|c|c|c|}
\hline Class & A & Levene Statistik & Sig. $(\boldsymbol{p})$ & Information \\
\hline Pre-test & 0,05 & 2,589 & 0,117 & Homogen \\
\hline Post-test & 0,05 & 0,826 & 0,370 & Homogen \\
\hline
\end{tabular}

Tabel 7 Post-test hypothesis testing results with $\mathrm{t}$ test

\begin{tabular}{|c|c|c|c|c|c|c|}
\hline No & Class & $\mathbf{N}$ & Results Class Average & t- count & t- table $\boldsymbol{\alpha}(\mathbf{0 , 0 5})$ & Information \\
\hline $\mathbf{1}$ & Experiment & 17 & 85,3 & \multirow{2}{*}{2,608} & 2,042 & \multirow{2}{*}{$\mathrm{H}_{0}$ rejected } \\
\hline $\mathbf{2}$ & Control & 17 & 78,429 & & \multirow{2}{*}{. } \\
\hline
\end{tabular}

Table 7 shows that there was an impact of farming on children's critical thinking ability (t-count $>\mathrm{t}$-table). It can be seen that the t-count was 2.608 whereas the t-table was 2.042 table. Those data taken from post-test of both groups.
This can be proven by chart above that shows the mean score of experimental group was higher than the control group where the mean of experimental group was 85.3 while the control group was 78.442. In conclusion, the 
farming activities conducted in kindergartens had an impact on children's critical thinking ability.

The finding prove that children could think critically, meaning that they could make make rational decisions about what to do or what to believe (Slavin, 2011: 37). Furthermore, it was in line with Nugraha (2008: 39) stated that the ability to think critically can be developed in early childhood by using materials and methods in accordance with the stages of children's critical thinking abilities in concrete terms. During implementation, a particular learning method such as farming used to involve children actively. It facilitated children to construct their own knowledge through observation analysis, proof, and conclusion about what they learned. Additionally, Ratnasari et al., (2016, p. 2) stated that farming activities provide opportunities for children to explore and to observe the surrounding environment and give the freedom to develop imagination and comprehend the truly meaning of learning while playing.

Farming activities can also develop children's critical thinking skills, for instance they know how to plant spinach, how to care for spinach and observe the growth process of spinach. Those fulfilled the concept of critical thinking include observing, identifying and analyzing. It also improved focus on the process of vegetable growth, starting from the seeds to leaves. Regardless, future research could continue to explore children's intellectual intelligence through farming activities.

\section{REFERENCES}

Desmita.(2010). Psikologi perkembangan peserta didik. Bandung: PT Remaja Rosdakarya

Natalina, D. (2015). Menumbuhkan perilaku berpikir kritis sejak anak usia dini. Jurnal Cakrawala Dini, 5(1).

Nugraha, A. (2005). Pengembangan pembelajaran sains pada anak usia dini. Jakarta: Depdiknas

Piaget, J. (1972). Intellectual evolution from adolescence to adulthood. Human development, 15(1), $1-12$.

Rahima. (2018). Berkebun organic buah dan sayur. Jakarta: Penebar Swadaya.

Rahman, H. S. (2005). Konsep dasar pendidikan anak usia dini. Yogyakarta: PGTKI Press.

Ratnasari, T., Sujana, Y., \& Pudyaningtyas, A. R. (2016). Pengaruh penerapan kegiatan berkebun terhadap perkembangan fisik motorik anak, 4(2). Retrieved from http://www.jurnal.fkip.uns.ac.id/index.php/paud/article/ view/8615.

Slavin, R. E. (2011). Psikologi pendidikan: Teori dan Praktik, Edisi Kesembilan, Jilid 2. Jakarta: Indeks.
Sugiyono, D. (2010). Metode penelitian kuantitatif dan $R \& D$. Bandung: Alfabeta.

Sugiyono. (2011). Metode penelitian kuantitatif, kualitatif dan R\&D. Bandung: Alfa Beta

Sugiyono. P. D. (2017). Metode penelitian kuantitatif, kualitatif, dan $R \& D$. Bandung: Alfa Beta

Susanto, A. (2012). Perkembangan anak usia dini. Jakarta: Kencana

Syafril. (2010). Statistika. Padang: Sukabina Press

Yasbiati, Y., Giyartini, R., \& Lutfiana, A. (2017).

Upaya meningkatkan kecerdasan naturalis melalui kegiatan bercocok tanam di bambim al-abror kecamatan mangkubumi kota tasikmalaya. Jurnal paud agapedia, 1(2), 203-213. 